\title{
Ultrasonography and Determination of Proteins and Enzymes in Blood for the Diagnosis of Liver Abscesses in Intensively Fed Beef Cattle
}

\author{
By P. Liberg and G. Jönsison \\ Experimental Station, Veterinary Institute, Skara, Sweden.
}

\begin{abstract}
Liberg, P. and G. Jönsson: Ultrasonography and determination of proteins and enzymes in blood for the diagnosis of liver abscesses in intensively fed beef cattle. Acta vet. scand. 1993, 34, 21-28. - The concentrations of plasma proteins and the activities of liver enzymes were measured every 2 weeks from weaning to slaughter in 21 beef cattle, and their livers were examined ultrasonographically every 4 weeks. Eight of the 9 cases of single or multiple liver abscesses were detected by ultrasonography but some individual abscesses, particularly those in the left side of the liver, remained undetected. The time at which the abscesses were first detected ranged from 4 to 20 (mean 12.5) weeks. There were only slight variations in the blood constituents and they were of no significant value in the diagnosis of the liver abscesses.
\end{abstract}

blood proteins; serum enzymes.

\section{Introduction}

Liver abscesses were not a major problem in cattle until the feeding of high concentrate diets became common. In Sweden, as elsewhere, the incidence of liver abscesses in intensively fed beef cattle varies widely between herds and between groups of animals within herds, but incidences between 30 and 60 per cent are not uncommon.

Fusobacterium necrophorum is the major organism responsible for the abscesses. It appears to gain access to the liver through lesions in the wall of the rumen.

The abscesses are said to start developing after 60 days on a fattening diet (Jensen \& Mackey 1971). An attempt to determine the time more precisely by serial measurements of the concentrations of serum proteins and the activities of liver enzymes was unsuccessful because no significant changes were detected, possibly because of the long intervals between samplings and the low antigenicity of $F$. necrophorum (Jönsson \& Liberg 1974).

Cattle with liver abscesses show no specific clinical signs, but a knowledge of when they develop is likely to be important both for understanding their pathogenesis and for instituting any adequate prophylaxis; a method for diagnosing liver abscesses in intensively fed calves is therefore urgently required.

Itabisashi et al. (1987) and Lechtenberg \& Nagaraja (1991) made ultrasonographic observations of bovine hepatic abscesses induced experimentally by the inoculation of $F$. necrophorum into the portal vein, and in a preliminary study, Jönsson et al . (1988) showed that 5 out of 6 natural cases of liver abscesses in intensively fed calves could be detected with ultrasonography from 6 to 15 weeks after they were weaned. The aim of the present study was to try to derive better information about the time at 
which liver abscesses develop - through more frequent ultrasonographic screenings and estimations of blood proteins and liver enzymes - and thereby obtain a better understanding of their pathogenesis.

\section{Materials and Methods}

Animals

Twenty-one Swedish Red and White bull calves were used. The study began at weaning when the calves were about 110 days old and weighed about $120 \mathrm{~kg}$. Fourteen of the calves were reared as barley beef bulls and received concentrate and hay ad lib. (Concentrate group), their average hay consumption was $0.7 \mathrm{~kg}$ per day. The other 7 were reared as concentrate/silage bulls (Silage group) and were given the roughage and concentrate in equal inputs of energy. The Concentrate group was slaughtered at 11 months of age when they weighed on average $440 \mathrm{~kg}$ and their average carcass weight was $230 \mathrm{~kg}$. The Silage group was slaughtered at 15 months of age when they weighed on average $480 \mathrm{~kg}$ and their average carcass weight was $250 \mathrm{~kg}$.

\section{Ultrasonography}

The equipment was an Aloka Echo Camera real-time sector scanner with a $3.5 \mathrm{MHz}$ probe and a 6-step selectable display range from 6 to $21 \mathrm{~cm}$. Every 4 weeks the 12 th to the 8th intercostal spaces were scanned in turn, from dorsal to ventral, usually with a reflective depth of 15 $\mathrm{cm}$. The ultrasonographic images were recorded by interfacing the ultrasound machine with a VHS video recorder.

\section{Clinical signs and serum biochemical values}

Observations on the calves' health and any necessary therapeutic treatments were recorded regularly. Every 2 weeks jugular blood samples were taken for the analysis of blood proteins and the enzymes aspartate transaminase (AST) and $\gamma$-glutamyltransferase $(\gamma-G T)$. Serum total protein was measured by the biuret method and serum albumin by the method of Doumas et al. (1971). The concentration of globulin and the albumin/globulin ratio were calculated from the total protein and albumin values. The serum proteins were separated electrophoretically on agarose gel by the method of Carlström \& Liberg (1975). Plasma fibrinogen was analysed by a syneresis method with thrombin clotting (Ek 1972). AST activity in serum was determined according to the method recommended by the Committee on Enzymes of the Scandinavian Society for Clinical Chemistry and Clinical Physiology (1974), using reagents from Boehringer Mannheim. $\gamma$-GT activity in serum was determined according to Szasz (1974) and Persijn \& van der Slik (1976), using reagents from Boehringer Mannheim.

\section{Necropsy}

At slaughter the livers were thoroughly examined for abscesses and scars; they were sliced serially to detect deep abscesses. Other organs were examined for gross lesions, and special attention was paid to clumped villi ("rosebuds") in the rumen wall, and signs of chronic pneumonia.

\section{Statistical analysis}

The group means on each occasion were compared by means of Student's t-test for independent samples. F-tests were used to determine whether the variances were equal. (SAS Institute Inc. 1987.)

Over the whole period the difference between the mean values of the groups was calculated and a paired t-test was used to determine whether the mean difference was significantly different from zero, i.e. whether the mean of one group differed consistently from the mean of the other. (SAS Institute Inc. 1987).

The changes in the differences between the group means with time were evaluated by a 
regression analysis with the mean difference as the dependent variable and time as the independent variable. (SAS Institute Inc. 1987).

\section{Results}

\section{Clinical signs}

Three weeks after the study began 4 of the calves had signs of pneumonia, they were cured by treatment with antibiotics. Otherwise all the calves remained healthy. The average daily weight gains were $1.3 \mathrm{~kg}$ for the Concentrate group and $1.0 \mathrm{~kg}$ for the Silage group.

\section{Ultrasonography}

Ultrasonographic evidence of single or multiple liver abscesses was observed in 8 of the calves (38\%), 6 in the Concentrate group and 2 in the Silage group. The lesions initially appeared as circular hyperechoic areas, but later the hyperechoic abscess capsules enclosed an area which varied from black (anechoic) to almost white (hyperechoic). The lesions ranged from 1 to $10 \mathrm{~cm}$ in diameter, and they were usually best visualised in the 11th to the 9th intercostal space. The time when they were first observed ranged from 4 to 20 (mean 12.5) weeks after weaning.

As the calves developed a larger abdomen it became more difficult to obtain a good ultrasonographic echo from the liver. This was most evident in the Silage group. Moreover, as the calves grew the intercostal spaces became narrower and the ultrasonography was more difficult to perform.

\section{Necropsy}

At necropsy liver abscesses were found in 9 of the animals (43\%), including the 8 in which they had been detected ultrasonographically; the ninth had only a single abscess. In 5 of the animals which had multiple liver abscesses the ultrasonographic examination had suggested that there were fewer abscesses. One or 2 scars were found in the livers of 3 other animals and in these the ultrasonographic examination had failed to detect any pathological changes. Nine of the animals had no signs of liver injury either at necropsy or during the ultrasonographic examinations. The incidence of liver pathology was 71 per cent in the Concentrate group (10 animals) and 29 per cent in the Silage group ( 2 animals); the 3 animals with scars were all in the Concentrate group.

The gross examination of the rumen wall revealed the presence of a few "rosebuds" in 1 animal with liver abscesses and in 2 of the animals without them. There were slight signs of pneumonia in 1 animal with abscesses and in 1 animal without them, and also in the 3 animals with liver scars.

\section{Blood changes}

Comparisons were made between the animals with abscesses (Abscess group, $\mathrm{n}=9$ ) and the animals without them (Non-abscess group, $n=9$ ), and the 3 animals with liver scars were omitted from the comparisons. The results of the comparisons between group means are shown in Figs. $1-5$.

Serum total protein (Fig.1). There were no significant differences between the groups either at any individual sampling or on average over the whole period. However, a regression analysis revealed a significant increase in the difference between the group mean values with time $(p<0.01)$ : at first the mean total protein concentration was lower in the Abscess group but during the trial it increased until it was higher than in the Non-abscess group.

Serum albumin (Fig.1). On 2 occasions towards the end of the trial the concentration of albumin was slightly but significantly lower in the Abscess group $(\mathrm{p}<0.05)$. The overall mean albumin concentration of the Abscess 


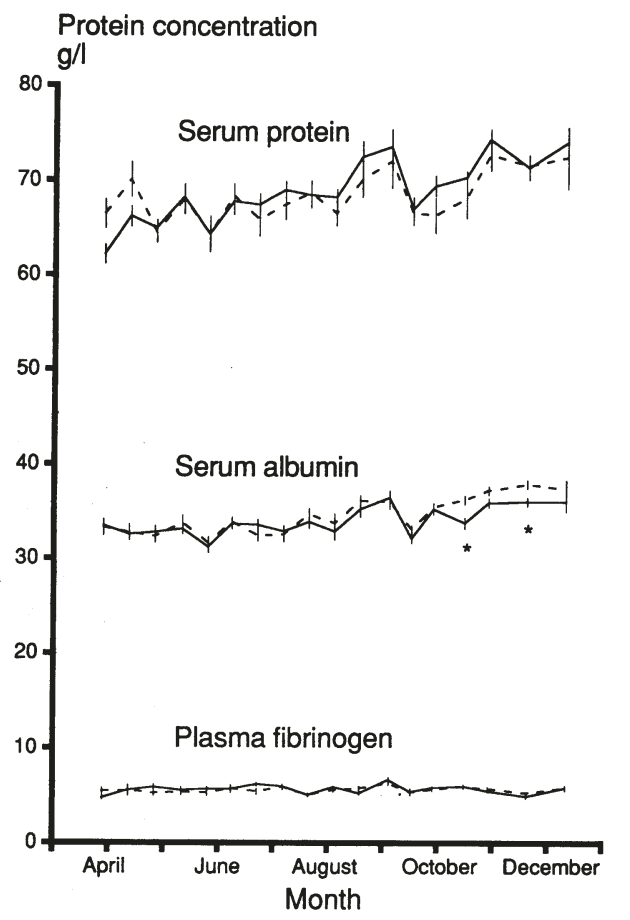

Figüre 1. Mean $( \pm \mathrm{SE})$ serum protein, -albumin and plasma fibrinogen concentrations measured every 2 weeks from weaning to slaughter in beef cattle with liver abscesses (-) and without liver abscesses (--). Differences between group means in Figs. 1-5: * $\mathrm{p}<0.05 ; * * \mathrm{p}<0,01 ; * * * \mathrm{p}<0.001$.

group was also lower than that of the Non-abscess group $(\mathrm{p}<0.05)$. Furthermore, a regression analysis showed that the difference between the group mean values increased with time $(\mathrm{p}<0.05)$.

Serum total globulin (Fig. 2). The mean concentrations of globulin were lower in the Abscess group at the first 2 samplings but slightly higher at all the other samplings. The difference between groups was, however, significant only at the first sampling. There was no significant mean difference between the groups, but there was a significant increase with time in the difference between the groups $(\mathrm{p}<0.001)$.

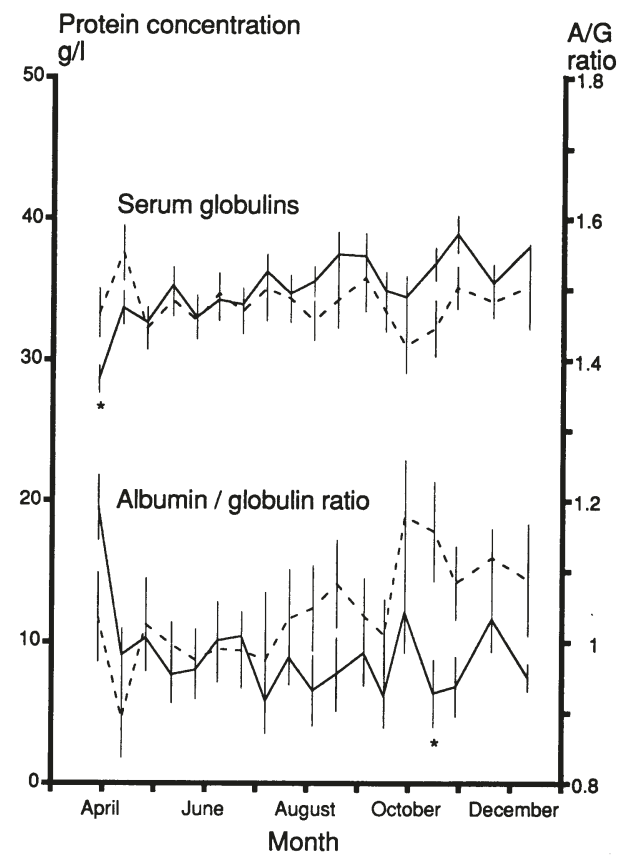

Figure 2. Mean $( \pm \mathrm{SE})$ serum total globulins and albu$\mathrm{min} /$ globulin ratio measured every 2 weeks in beef cattle with liver abscesses (-) and without liver abscesses (---).

Albumin/globulin ratio (Fig. 2). The lower albumin concentrations in the Abscess group towards the end of the trial resulted in a lower albumin/globulin ratio in this group on one occasion, and the mean values of the ratio were on average lower in this group $(\mathrm{p}<0.05)$. The difference between the groups increased during the trial $(\mathrm{p}<0.001)$.

Serum electrophoretic picture (Figs. 3 and 4 ). The concentration of $\alpha_{1}$-globulin was lower in the Abscess group on the first sampling occasion but its concentration in this group increased throughout the trial; as a result the average concentration of a $\alpha_{1}$-globulin was higher in the Abscess group than in the Non-abscess 




Figure 3. Mean ( $\pm \mathrm{SE}$ ) serum $\alpha_{1^{-}}, \alpha_{2}$ - and $\beta_{1}$-globulins measured every 2 weeks in beef cattle with liver abscesses (-) and without liver abscesses (----).

group $(p<0.05)$ and the difference between the groups increased during the trial $(\mathrm{p}<0.05)$.

There were no significant differences between the groups with respect to the concentration of $\alpha_{2}$-globulin .

The concentration of $\beta_{1}$-globulin was significantly higher in the Abscess group on several occasions, and on average there was a highly significant difference between the groups $(\mathrm{p}<0.001)$. However, there was no significant change in the difference with time.

The concentration of $\beta_{2}$-globulin in the 2 groups did not differ significantly on any single occasion or on average throughout the trial. However, initially the mean concentration of $\beta_{2}$-globulin was lower in the Abscess group, but it



Figure 4. Mean $\left( \pm\right.$ SE) serum $\beta_{2}$ - and $\gamma$-globulins measured every 2 weeks in beef cattle with liver abscesses (-) and without abscesses (---).

became higher than in the Non-abscess group at the end of the trial; the difference between the groups increased significantly with time $(\mathrm{p}<0.01)$. The mean $\gamma$-globulin concentrations were significantly lower in the Abscess group on the second and fifth sampling occasions $(\mathrm{p}<0.01$ and $\mathrm{p}<0.05$ respectively). On average the $\gamma$-globulin concentrations in the Abscess group were lower than in the Non-abscess group $(\mathrm{p}<0.05)$. The concentration of $\gamma$-globulin increased during the trial in both groups, but the increase was greater in the Abscess group $(\mathrm{p}<0.01)$.

Plasma fibrinogen (Fig. 1). There were no significant differences between the plasma fibrinogen concentrations of the 2 groups. 


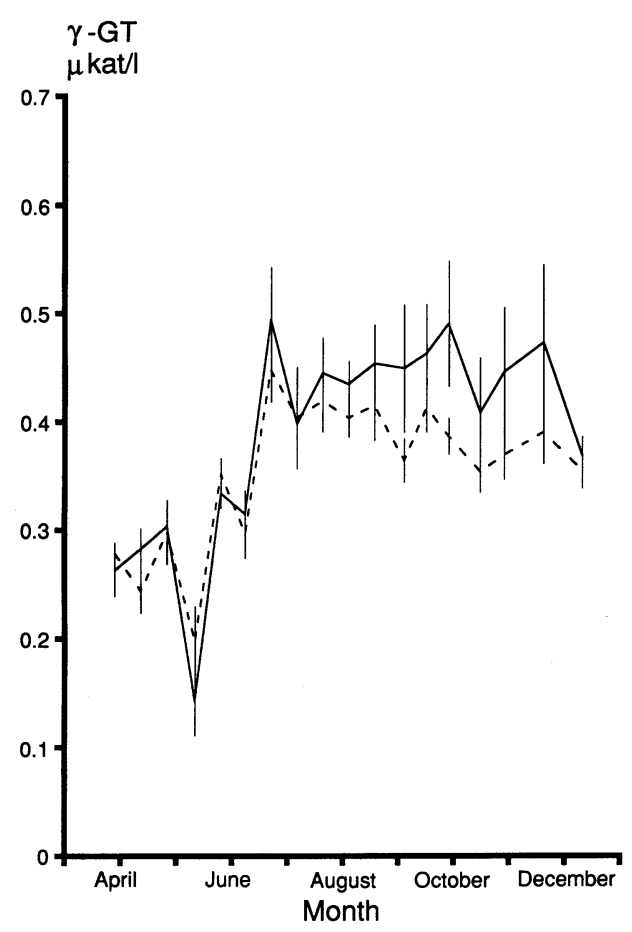

Figure 5. Mean (+ SE) serum $\gamma$-glutamyltransferase measured every 2 weeks in beef cattle with liver abscesses (-) and without liver abscesses (----).

Serum enzymes. The activity of AST was very low in both groups throughout the trial. There were no significant differences between the mean activities of $\gamma$-GT in the 2 groups on any single occasion (Fig. 5), but on average the activity of this enzyme was higher in the Abscess group $(\mathrm{p}<0.01)$ and the difference between the groups increased with time $(\mathrm{p}<0.01)$.

\section{Discussion}

Although the factors affecting the development of liver abscesses are not fully understood, most investigations suggest that the diet plays an important role. A reduction in the proportion of concentrate and an increase in the proportion of roughage in the ration has been shown to reduce the incidence of liver abscesses in intensively reared cattle (Szemeredy \& Raul 1976, Gill et al. 1979, Mossberg et al. 1993) and in the present trial the incidence of abscesses in the Silage group, which had a concentrate/roughage ratio of 50/50, was less than half that in the Concentrate group, which had a concentrate/roughage ratio of more than 95 to 5 . Nevertheless, it is clear that increasing the proportion of roughage in the ration is not an adequate method of preventing liver abscesses.

In practice liver abscesses are always diagnosed post mortem, because there are either no clinical signs or the signs are non-specific. To obtain a better understanding of the pathogenesis of liver abscesses it would be valuable to discover whether they begin to develop at any particular time during the rearing of intensively fed cattle.

It has been shown that ultrasonography can detect liver abscesses in cattle. In a preliminary study (Jönsson et al. 1988) most naturally occurring cases of abscesses were diagnosed, and in the present study 8 of the 9 animals which had abscesses post mortem were diagnosed ultrasonographically. However, the ultrasonographic technique did not reveal all the abscesses in 5 animals which had more than 1 abscess. Furthermore, as the animals grew larger and the intercostal spaces became narrower it became more difficult to obtain a good ultrasonographic echo, particularly in the animals of the Silage group. The ultrasonographic picture did not cover the entire liver. Abscesses in the left side of the liver lay beyond the reflection depth of the $3.5 \mathrm{MHz}$ transducer. As a result ultrasonography has limited value for the clinical diagnosis of liver abscesses in older and/or fat cattle with large abdomens.

In spite of these limitations these ultrasonographic studies demonstrate that the liver abscesses began to develop at widely different times dur- 
ing the rearing of the animals. In the preliminary study abscesses were first detected between 6 and 15 weeks after weaning and in the present study they were detected between 4 and 20 weeks after weaning. As a result it is clear that the risk of liver abscessation is spread throughout the rearing period, and it is not possible to recommend any effective prophylaxis, for example by short-term treatment with antibiotics.

The ultrasonographic examinations failed to detect the 3 animals which had scars in their livers post mortem. The scars were small and may not have been related to abscesses in any way. When liver abscesses are induced experimentally they do not become visible ultrasonographically until the coagulative necrosis of hepatocytes and neutrophils forms distinct areas of fluid with a necrotic core in the centre; these lesions develop 3-8 days after inoculation (Lechtenberg \& Nagaraja 1991). The abscesses disappear from the ultrasonographic picture when the central necrotic mass diminishes in size and the abscess is gradually replaced by granulation tissue and capsule, and becomes a scar (Itabisahashi et al. 1987).

The failure of an earlier attempt to determine when liver abscesses developed in intensively fed cattle by measuring blood protein concentrations and liver enzyme activities once a month (Jönsson \& Liberg 1974) led to the bi-weekly sampling schedule used in the present study. However, the changes observed in protein concentrations and enzyme activities were small, and although there were significant differences between the groups with and without abscesses they were usually not large enough to be used reliably for diagnosis. Moreover, the changes gave no reliable guide to the onset of the development of the abscesses in these animals.

According to the earlier investigation (Jönsson \& Liberg 1974) no pronounced changes in the concentrations of immunoglobulins $\left(\gamma\right.$-and $\beta_{2}-$ globulins) would be expected in cattle with liv- er abscesses. However, with the more frequent sampling schedule, changes in serum $\alpha$-globulins and plasma fibrinogen - representing the acute phase reaction - might have been expected. However, no changes of diagnostic value were observed.

Blood samples taken daily for eight days from cattle with experimentally induced liver abscesses revealed increases in the concentration of globulin and in the activities of AST and $\gamma$-GT. In the present study the changes observed in enzyme activities were unhelpful in identifying when the abscesses started to develop. It appears that much more frequent sampling might make it possible to diagnose the development of naturally occurring liver abscesses satisfactorily, but daily samplings were far beyond the practical limitations of the present study.

\section{Acknowledgements}

The investigation was supported financially by The Swedish Farmers' Foundation for Agricultural Research. The close cooperation with Dr. Sölve Johnsson and his coworkers, Western District of Animal Research, Skara, Sweden, is highly appreciated.

\section{References}

Anonymous: Committee on Enzymes of the Scandinavian Society for Clinical Chemistry and Clinical Physiology: Recommended methods for the determination of four enzymes in blood. Scand. J. clin. Lab. Invest. 1974, 33, 292-306.

Carlström G, Liberg P: Agarose gel electrophoretic separation of blood serum proteins in cattle. Acta vet. scand. 1975, 16, 520-524.

Doumas BG, Watson WA, Biggs HG: Albumin standards and the measurement of serum albumin with bromocresol green. Clin. Chem. Acta 1971, 31, 87-96.

$E k N$ : The quantitative determination of fibrinogen in normal bovine plasma and in cows with inflammatory conditions. Acta vet. scand. 1972, 13, 175184.

Gill DR, Owens FN, Fent RW, Fulton RK: Thiopeptin and roughage levels for feedlot steers. J. Anim. Sci. 1979, 49, 1145-1150.

Itabisashi T, Yamamoto R, Satoh M: Ultrasonogram of hepatic abscesses in cattle inoculated with Fuso- 
bacterium necrophorum. Jap. J. vet. Sci 1987, 49, 585-592

Jensen R, Mackey DR: Diseases of feedlot cattle. Lea \& Febiger, Philadelphia 1971.

Jönsson G, Bergsten C, Carlsten J, Johnsson S, Liberg $P$ : Ultrasonic diagnosis of liver abscesses in intensively fed beef cattle. Proc. 15th World Buiatrics Congress, Palma de Mallorca 1988, 1428-1430.

Jönsson G, Liberg P: Liver abscesses in intensively fed cattle. Serial investigations of serum proteins. Acta vet. scand. 1974, 15, 264-273.

Lechtenberg KF, Nagaraja TG: Hepatic ultrasonography and blood changes in cattle with experimentally induced hepatic abscesses. Amer. J. vet. Res. 1991, 52, 803-809

Mossberg I, Lindell L, Johnsson S, Törnquist M: Insulated and urinsulated housing system for growing bulls fed grass silage ad lib.. Acta agric. scand. 1993 (in press).

Persijn JP, van der Slik W: A new method for the determination of $\gamma$-glutamyl transferase in serum. J. clin. Chem. Biochem. 1976, 14, 421-427.

Szasz G, Weimann G, Stähler S, Wahle AW, Persijn JP: New substrates for measuring $\gamma$-glutamyl transpeptidase activity. Z. Klin. Chem. u. Klin. Biochem. 1974, 12, 228.
Szemeredy GY, Raul R: Alterations of the ruminal mucosa and its relation to the hepatic abscesses in bulls fed high energy and low fibre diets. Acta vet. Acad. Sci. hung. 1976, 26 ,313-324.

SAS Institute Inc.: SAS/STAT Users Guide. Release 6 Edition. Cary, NC 1987, 1028 pp.

\section{Sammanfattning}

Ultraljudsundersökningar samt bestämning av proteinmönster och enzymaktiviter $i$ blod för diagnos av leverbölder hos intensivt uppfödda ungnöt.

Ultraljudsundersökningar av levern utfördes var fjärde vecka och blodprov för bestämning av proteiner och enzymer togs varannan vecka på 14 gödtjurar och 7 vallfodertjurar under hela uppfödningsperioden. Sju gödtjurar och 2 vallfodertjurar hade vid slakt bölder i levern. Av dessa 9 leverböldsfall kunde 8 upptäckas intravitalt med ultraljud.Enskilda bölder, företrädesvis sådana belägna $i$ leverns vänstra del, undgick upptäckt med ultraljudet.Tidpunkten för första upptäckt med ultraljud av leverböldsbildning varierade mellan 4 och 20 (medeltal 12.5) veckor från avvänjningen. Skillnaderna i proteinmönster och enzymaktiviter mellan djur med och utan bölder var blygsamma och utan diagnostiskt värde.

(Received September 29, 1992; accepted October 1, 1992).

Reprints may be requested from: P. Liberg, Experimental Station, Veterinary Institute, P.O.Box 234, S-532 23 Skara, Sweden. 